\title{
Intergrated Use of Geo-Electric Resistivity Sounding and Hydrogeologic Investigations for Groundwater Resource Development around Obu-Okpella South-Western Nigeria.
}

\author{
C.B. Longpia ${ }^{1}$, P.D. Dakwo ${ }^{2}$, J.A. Ramadan ${ }^{1}$, J.O Ikeh ${ }^{3} \&$ C.J Offodile ${ }^{3}$ \\ ${ }^{1 .}$ Department of Mineral \& Petroleum Engineering Plateau State Polytechnic, B/Ladi \\ ${ }^{2}$. Longpigrand Geotechnics Ltd, No. 4 b Kufang, Miango Road, Jos \\ ${ }^{3}$. Mecon Geology and Engineering Service Ltd. Jos
}

\begin{abstract}
An intergrated use of geo-electrical resistivity soundings and hydrogeologic methods were employed in the investigation for groundwater resource, evaluation and development around Obu-Okpella, near BUA cement factory, South-western Nigeria. The study area is underlain by Basement Complex rocks which consist of migmatites, granite gneiss and pegmatites. A total of 35 vertical electric soundings (VES) and four exploratory boreholes were carried out in the study. The geo-electric resistivity sounding data were interpreted using IXD interpex software and the VES interpretation revealed 4 geo-electric layers/lithologic units from the geo-electric parameters. The geo-electric layers are- (1) Topsoil from 0 to $2.5 \mathrm{~m}$, (2) weathered basement from 3.3 to $49 \mathrm{~m}$, (3) Slightly weathered/Fresh basement from $5 \mathrm{~m}$ to $\infty$, (4) Fractured basement ( $\geq 5$ to 150m) and are characterised by resistivity value range of 14 to $297 \mathrm{ohm}-\mathrm{m}, 16$ to $98 \mathrm{ohm}-\mathrm{m},>1000 \mathrm{ohm}-\mathrm{m}$ and < 50 to $31056 \mathrm{ohm}-\mathrm{m}$ respectively. Four exploratory boreholes numbered $\mathrm{BH} 1, \mathrm{BH} 2, \mathrm{BH} 3$, and $\mathrm{BH} 4$ were drilled on VES 1, 17, 18 and 31 to a depth of 180, 150, 58 and $110 m$ respectively. The VES interpretation and borehole lithologic logs were well correlated. The main aquifer is in the deep and highly fractured basement rocks with average depth of 50-150m. The pumping test results for the boreholes number $\mathrm{BH} 1, \mathrm{BH} 2, \mathrm{BH} 3$ and $\mathrm{BH} 4$ were $0.81 / \mathrm{s}, 1.871 / \mathrm{s}, 1.2 \mathrm{l} / \mathrm{s}$ and $1.7 \mathrm{l} / \mathrm{s}$ respectively with very maximum dynamic water level of $<10 \mathrm{~m}$. Transitivity value of the aquifer for $\mathrm{BH} 1, \mathrm{BH} 2, \mathrm{BH} 3$ and $\mathrm{BH} 4$ are 2.58 $\mathrm{m}^{2} /$ day, $21.43 \mathrm{~m}^{2} /$ day, $55.62 \mathrm{~m}^{2} /$ day, and $37.98 \mathrm{~m}^{2} /$ day respectively indicates that the lithostratas constituting the aquifer is fair in transmitting the groundwater. With a volume of 12,000 l/day, 97,000 l/day, 91,000 l/day and 51,840 l/day for BH1, BH2, BH3 and BH4, the total volume of water for the four boreholes is 253,560 l/day.
\end{abstract}

Keywords: Obu-Okpella, Geoelectric/Hydrogeologic investigations, Borehole flow rates and tranmissivity.

\section{Introduction}

Obu-Okpella is one of the rapidly expanding satellite town northeastern part of Edo State. It is strategically important because of its industrial mineral resources, which include marble and granitic rocks. The marble is being quarried for cement production by BUA Cement Company. The building of a new cement plant and its subsequent expansion over the last decade has resulted rapid expansion of the settlement with increased population around the cement factory. As a result of the increased population water supply for domestic and industrial purposes from the groundwater resources and few boreholes with characteristically low yield have been overstretched and grossly inadequate. Geophysical investigations have been used overtime and successfully to determine the subsurface sequences, aquifer units and also tomap lateral and vertical extends (Olurufemi, 1985; Omosuyi et al, 1999).

Lithosthratigraphic units from drilled boreholes have been used to identify aquifer units in its laterally, and vertical extends (Longpia et al 2004). A geophysical investigation using vertical electrical soundings (VES) technique and exploratory borehole programmes was employed to determine the disposition/hydrogeophysical characteristics and geologic segments of the area with a view of developing a sustainable small to medium water supply scheme using groundwater resources.

\section{Location And Physiography.}

The study area is located between UTM co-ordinates of longitude 212000 to 214000 Easting and 813200 to 814400 Northing. The climate falls within the warm-humid tropical climate region which is characterized by wet and dry season. 


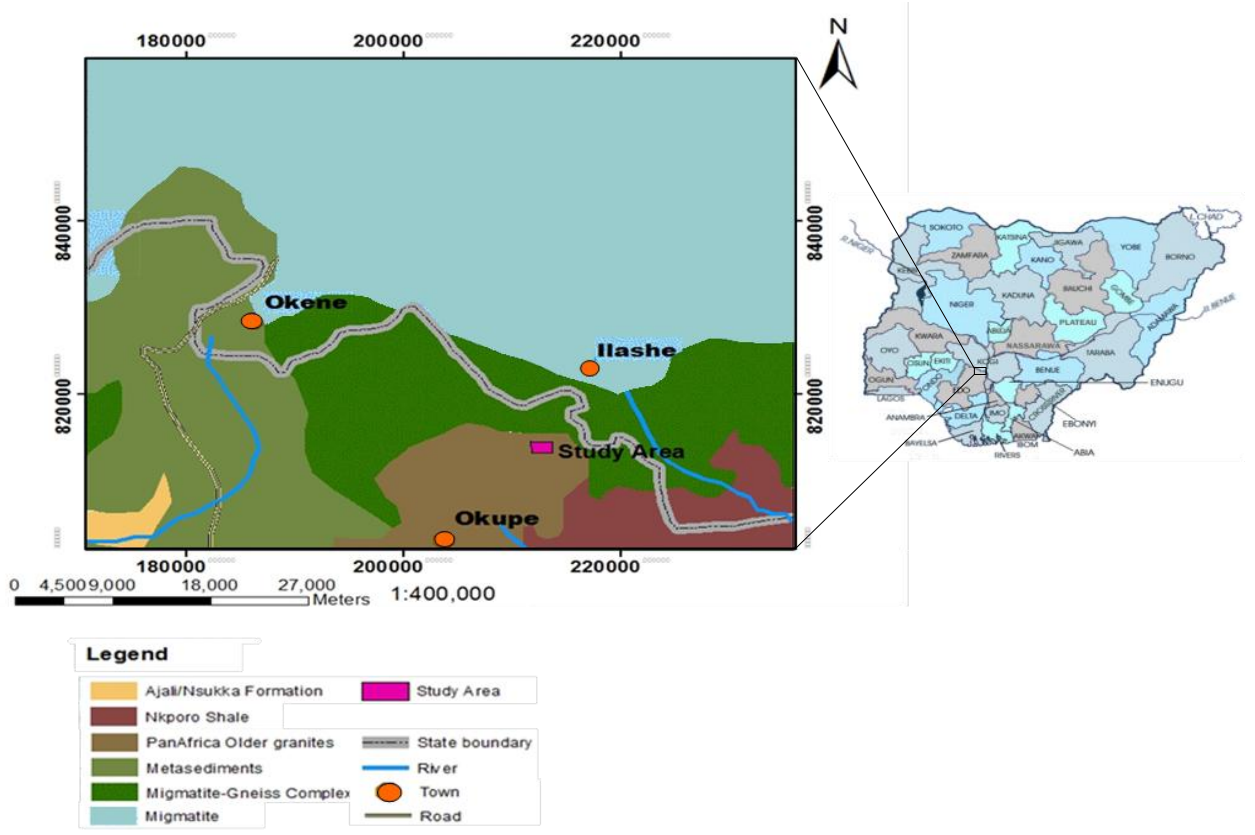

Fig. 1: Regional Geology of the Study area.

The vegetation cover is typically that of the Guinea Savannah and characterized by secondary vegetation of scattered trees, shrubs and grass savannah. Generally, the vegetation has been tempered by human activities mainly for agricultural purposes.

\section{GEOLOGY}

\section{Regional Geology}

The Pre-cambrian geology of the south-western Nigeria is part of the Basement Complex rocks of the south-west Nigeria. According to Rahaman (1989), five major groups of rocks have been recognized in the regional setting consisting of:

i) Migmatised-Gniess Complex

ii) Slightly migmatised to unmigmatised para schists and meta igneous rocks which consists of pellitic schist, quartzite, amphibolites, talcose rocks, meta conglomerates, marbles, calc-silicate rocks,

iii) Charnokitic rocks,

iv) Older Granites comprising of rocks with granodiorite to true granite and potassium synite.

v) Unmetamorphosed dolerite dykes.

From Igara and further east around Okpella, the association of amphibolites (meta igneous and volcanic rocks) and the association of carbonates (marbles and calc-silicates rocks) and argillaceous rocks are to represent an eugeosnclined and miogeosyncline sequence of sediments (Rahaman, 1989).

\section{Local Geology setting.}

Obu-Okpella and environs is underlain mainly by the Migmatite-Gneissic Complex and Older Granite (Fig. 1). The Meta sediments consist of Marbles, which is quarried for cement production. The Migmatite-Gneiss Complex is highly fractured and characterized by highly dissected stream/rivers. The rivers appear to follow the lineaments or local structures.

\section{HYDROGEOLOGY}

Hydrogeologically, the study area falls within the crystalline basement complex and are classified as poor groundwater regions (du Preeze and Berber, 1965). However, despite the relatively poor hydrogeological characteristics of these basement rocks, they have remained a very important source of water supply for more than half of the population of rural areas in Nigeria (Offodile, 2002). The weathered regoliths usually consist mainly of clays, sands, sandy clays and where generally thick, constitute the aquifers (Offodile, 1983). Highly tectonised basement rocks with incipient fractures, joints and folds are potential groundwater storage and flow zones and is very significant in basement surveys for groundwater development (Omosuyi et'al, 2003).

\begin{tabular}{lll}
\hline DOI: 10.9790/0990-0503026472 & www.iosrjournals.org & $65 \mid$ Page
\end{tabular}




\section{METHOD OF STUDY}

\section{Geophysical Survey.}

This study involved the geo-electrical resistivity measurement across the accessible areas south of the factory area (BUA Cement) (Fig. 2). The survey was conducted using the Schlumberger Array (vertical electrical sounding) method. The current electrode $(\mathrm{AB} / 2)$ and potential electrode separations (MN/2) was varied from 1.5 to $500 \mathrm{~m}$ and from 0.5 to $55 \mathrm{~m}$ respectively. The field readings were carried out using Allied Ohmega earth resistivity meter. A total of 35 VES were conducted around the area (Fig. 2). The field data was interpreted using a computer simulated program, Interpex (IXD) software.

The geo-electrical parameters of the VES interpretation were used to produce geo-electric sections along strategic profile. The VES locations co-ordinates were determine in the field by the use of Garmin Etrex 12 channel global positioning system. The maps were produced using Surfer 11 GIS program.

\section{Hydrogeologic Investigation.}

Four exploratory boreholes were drilled on fractured basements as revealed by the VES interpretations to determine the aquiferous nature or characteristics of the geologic structures within the area of study were obtained and were used for correlation with the VES interpretations (Fig. 5).

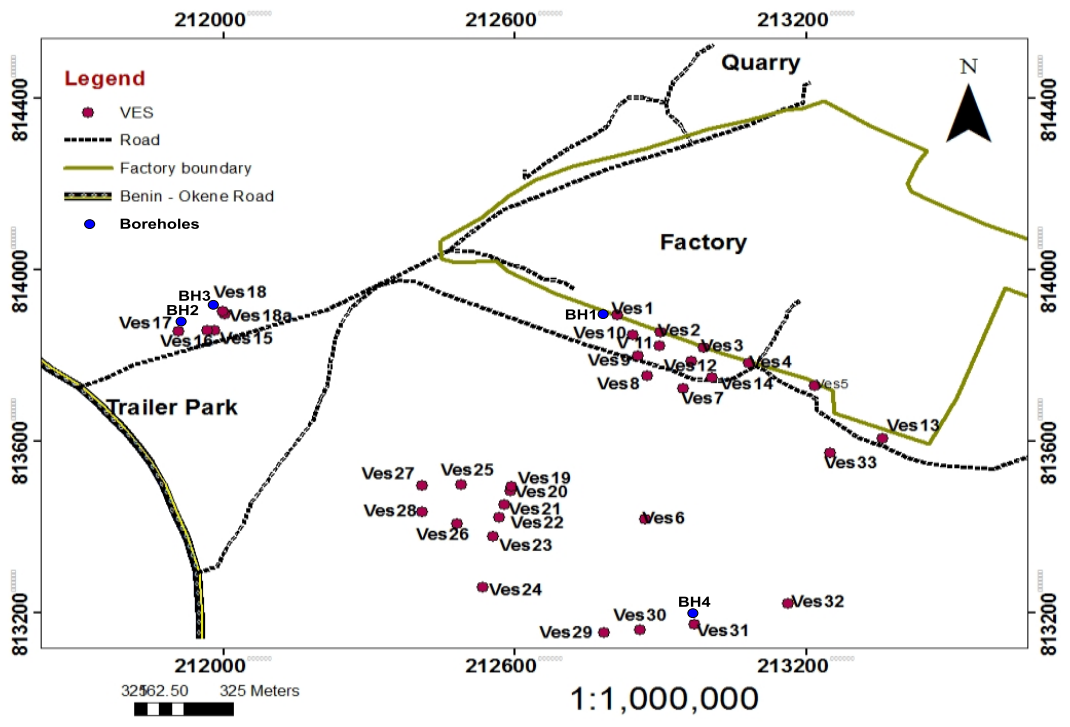

Fig. 2: Location Map of the Study area showing VES Locations

\section{Results \& Discussion}

Geo-electric Resistivity Soundings and Interpretations.

The computer model interpretation of the 34 VES are as shown in Table 1. 
Table 1: Summary of VES Interpretation

\begin{tabular}{|c|c|c|c|}
\hline VES No. & Depth (m) d1/d2-----dn & Resistivity (ohm-m) $\ell 1 / \ell 2------\ell n$ & Curve type \\
\hline 1 & $2.5 / 8.2 / 33.8 / \infty$ & $110 / 72 / 727 / 92$ & KHK \\
\hline 2 & $0.8 / 4.0 / 16.6 / \infty$ & $15 / 10 / 305 / 82$ & $\mathrm{AK}$ \\
\hline 3 & $3.2 / 17.0 / 34.8 / 114.8 / \infty$ & $292 / 58 / 319 / 71 / 225$ & KHKA \\
\hline 4 & $0.6 / 13.7 / 23.0 / 49.7 / \infty$ & $26 / 22 / 147 / 114 / 207$ & HKA \\
\hline 5 & $1.6 / 13.1 / \infty$ & $33.7 / 22 / 462$ & HA \\
\hline 6 & $1.0 / 29.7 / \infty$ & $51 / 28 / 1319$ & $\mathrm{HA}$ \\
\hline 7 & $0.8 / 17.8 / \infty$ & $10 / 6 / 555$ & HA \\
\hline 8 & $0.6 / 49.7 / \infty$ & $54 / 31 / 187$ & HA \\
\hline 9 & $0.8 / 5.1 / 33.8 / \infty$ & $101 / 52 / 396 / 142$ & HKA \\
\hline 10 & $0.8 / 8.3 / 27.4 / \infty$ & $92 / 35 / 789 / 127$ & $\mathrm{HK}$ \\
\hline 11 & $0.6 / 4.0 / 13.1 / \infty$ & $26 / 10 / 656 / 229$ & $\mathrm{HK}$ \\
\hline 12 & $0.8 / 5.1 / 87.2 / \infty$ & $37 / 17 / 266 / 255$ & $\mathrm{HK}$ \\
\hline 13 & $0.8 / 2.3 / \infty$ & $34 / 50 / 1371$ & $\mathrm{~A}$ \\
\hline 14 & $0.5 / 2.3 / 23.0 / \infty$ & $49 / 24 / 261 / 72 / 204$ & AKA \\
\hline 15 & $0.6 / 2.0 / \infty$ & $30 / 98 / 2736$ & $\mathrm{~A}$ \\
\hline 16 & $1.0 / 6.7 / 95.4 / \infty$ & $68 / 120 / 1030 / 515$ & $\mathrm{AK}$ \\
\hline 17 & $0.5 / 2.5 / 8.2 / 26.7 / \infty$ & $38 / 93 / 359 / 238 / 1099$ & AKA \\
\hline 18 & $0.6 / 2.5 / 21 / \infty$ & $75 / 90 / 1697 / 655$ & $\mathrm{AK}$ \\
\hline 19 & $1.0 / 6.6 / \infty$ & $22 / 75 / 3075$ & $\mathrm{~A}$ \\
\hline 20 & $3.2 / 8.3 / \infty$ & $5 / 34 / 21941$ & $\mathrm{~A}$ \\
\hline 21 & $0.6 / 4.2 / 17.7 / 121 / \infty$ & $44 / 29 / 1287 / 209 / 603$ & HKA \\
\hline 22 & $1.2 / 10.3 / \infty$ & $7 / 5 / 4525$ & HA \\
\hline 23 & $0.5 / 3.3 / 5.3 / 46.3 / \infty$ & $51 / 22 / 178 / 36 / 811$ & HKA \\
\hline 24 & $0.5 / 3.3 / 5.3 / 46.3 / 154 / \infty$ & $52 / 24 / 155 / 44 / 598 / 456$ & HKAK \\
\hline 25 & $1.3 / 17.7 / 121 / \infty$ & $13 / 36 / 762 / 755$ & $\mathrm{AK}$ \\
\hline 26 & $0.5 / 3.3 / 1249 / 329 / \infty$ & $43 / 27 / 1249 / 329$ & HAK \\
\hline 27 & $0.5 / 3.3 / 75 / \infty$ & $128 / 74 / 7950 / 2129$ & HAK \\
\hline 28 & $0.6 / 3.3 / 22.5 / \infty$ & $26 / 14 / 31179 / 12422$ & HAK \\
\hline 29 & $0.8 / 8.6 / 58.9 / \infty$ & $684 / 85 / 2600 / 889$ & HAK \\
\hline 30 & $0.6 / 8.6 / 58.9 / \infty$ & $26 / 45 / 73350 / 31056$ & $\mathrm{AK}$ \\
\hline 31 & $1.0 / 13.9 / 58.9 / \infty$ & $85 / 21 / 368 / 165$ & $\mathrm{HK}$ \\
\hline 32 & $1.3 / 46.3 / \infty$ & $29 / 16 / 185780$ & HA \\
\hline 33 & $0.8 / 4.2 / 13.9 / 121 / \infty$ & $64 / 37 / 1210 / 104 / 290$ & HKA \\
\hline 34 & $1.6 / 17.7 / 154 / \infty$ & $137 / 46 / 4503 / 3824$ & HAK \\
\hline
\end{tabular}

OBU VES 1

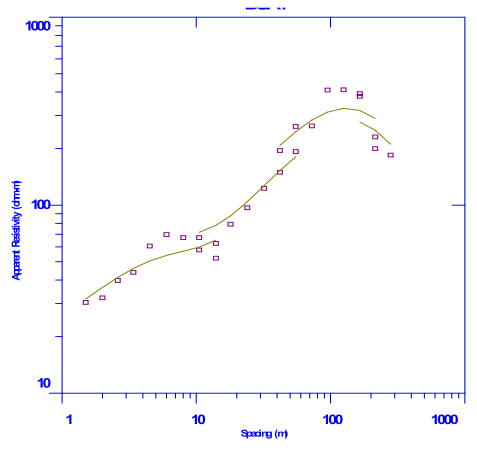

a

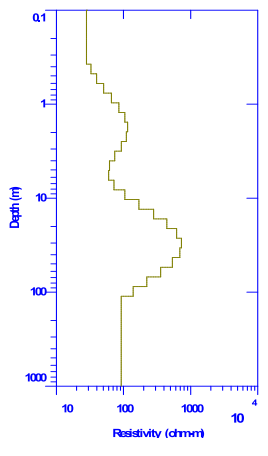

Tos curves withi
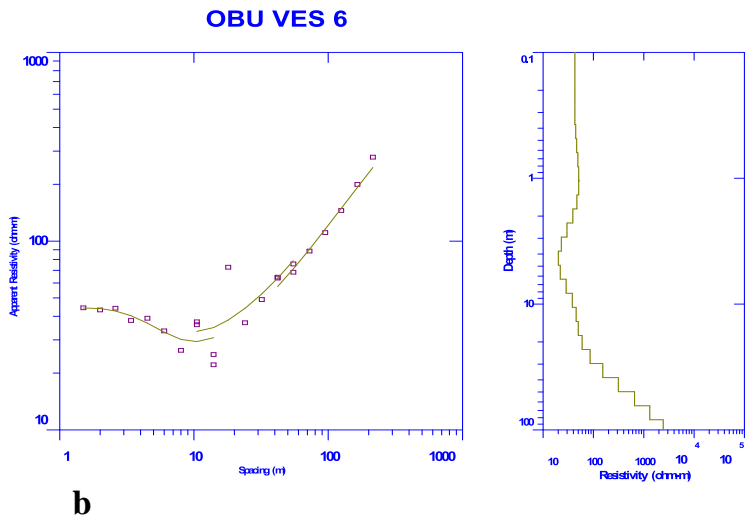

Fig. 3: Typical VES curves within the study area.

\section{Geo-electric Sequence}

The VES data interpretation delineates four major lithologic/geologic units: (i) Topsoil, (ii) lateritic layer, (iii) weathered layer, (iv) bedrock and (v) fractured bedrock. The geo-electric sections were taken in three directions NW-SE, N-S and W-S (Fig.4) in an attempt to correlate the geo-electric sequence across the study area. The topsoil has variable thickness ranging from 0.5 to $3.2 \mathrm{~m}$ and characterized by resistivity value of 14 to 297 ohm-m. The layer thickness is variable from 0.5 to $3.2 \mathrm{~m}$. The second layer is weathered basement consisting (sands, sandy clay and clays) with variable thickness from 3.3 to $49 \mathrm{~m}$ and characterized by resistivity varies range from 16 to 98 ohm-m (Table 1\& Fig.4). This layer is characterized by low to moderate resistivity. The low resistivity characteristics in this type of layers are most-likely, controlled by its water saturation (Omosuyi et'al, 2000). The third layer is bedrock 
and is characterized by high resistivity values from $>2600$ ohm-m to infinity. The fourth layer (Fig.4) which is fractured basement with variable depth of 7 to $150 \mathrm{~m}$ revealed values of $<50$ to $31056 \mathrm{ohm}-\mathrm{m}$ within the bedrock region and could be attributed to fracturing/shearing of the basement and possibly saturated by water (Olayinka \& Olorunfemi, 1991, Longpia et'al, 2013).
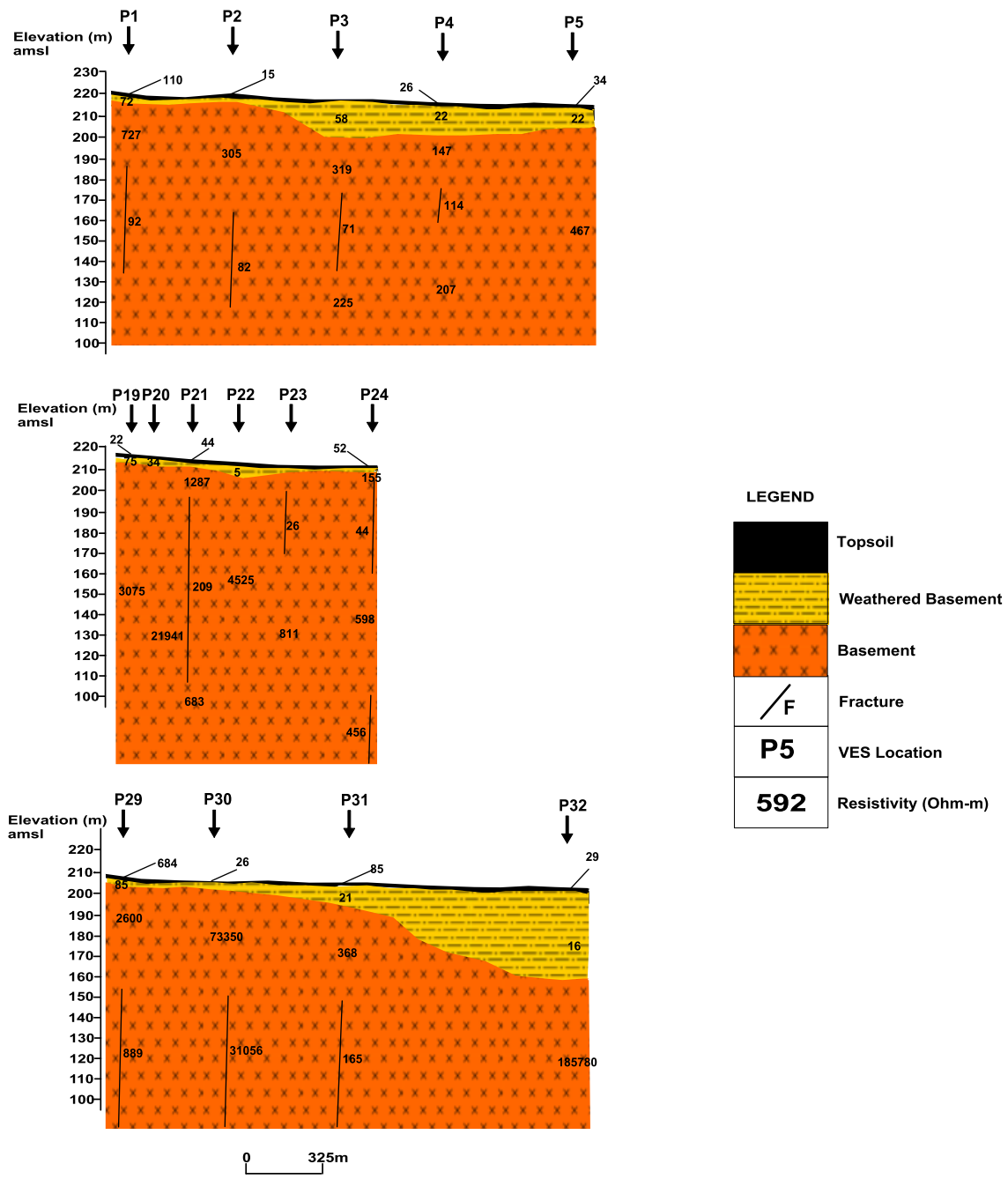

Fig.4: Geo-electric section in W-E and N-S directions.

\section{Groundwater Potential Evaluation.}

Significance of the weathered and fractured basement.

In crystalline basement hydrogeology, weathered overburden thickness with constituent material type, bedrock relief and structural settings are main factors in groundwater resources evaluation (Omosuyi et'al, 2003). The regolith and weathered basement layer and characterized by low to moderate resistivity, which may suggest saturation by water, constitutes the main aquifer (Balogun et'al, 2000). The bedrock relief/structures are very significant and hence the cardinal objective in basement groundwater surveys. Depressions filled with overburden materials and fractured bedrock constitute reliable and sustainable aquifer unit (Balogun et'al, 2000; Omosuyi et'al, 2003). In the groundwater potential assessment, geo-electric sections prepared from the geo-electric parameters of the geo-electric sounding interpretations were used. The lithologic and geoelectric sections revealed thin overburden which generally overlies the areas with isolated thick overburden in some areas. The main aquifer zones within the study area are the fractured basement. The thicknesses of the fractures are from $7 \mathrm{~m}$ to $150 \mathrm{~m}$ depth range (Fig. 4 and 5). 


\section{Exploratory Drilling Program}

Four exploratory boreholes (BH1, BH2, $\mathrm{BH} 3$ and $\mathrm{BH} 4)$ were drilled to various depths on VES 1, VES 18, VES 17 and VES 31 respectively (Fig. 5 and Table 2). The drilled lithologic/geologic logs revealed that the aquifers are within the highly fractured basement from $7 \mathrm{~m}$ to $180 \mathrm{~m}$ (Fig. 5). The fractures are possibly the main conduits for flow and storage of groundwater within the area.

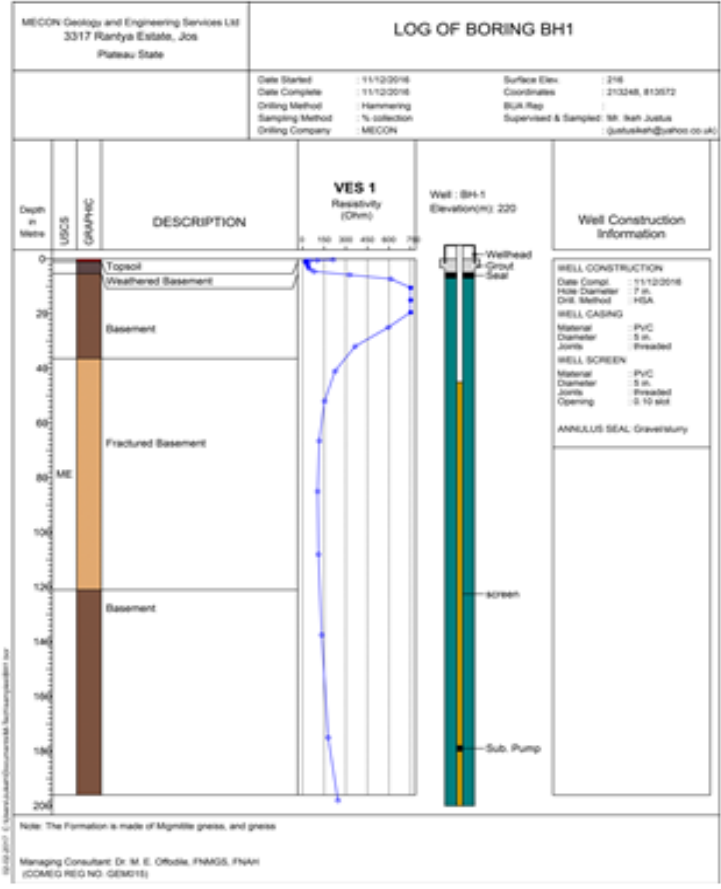

a

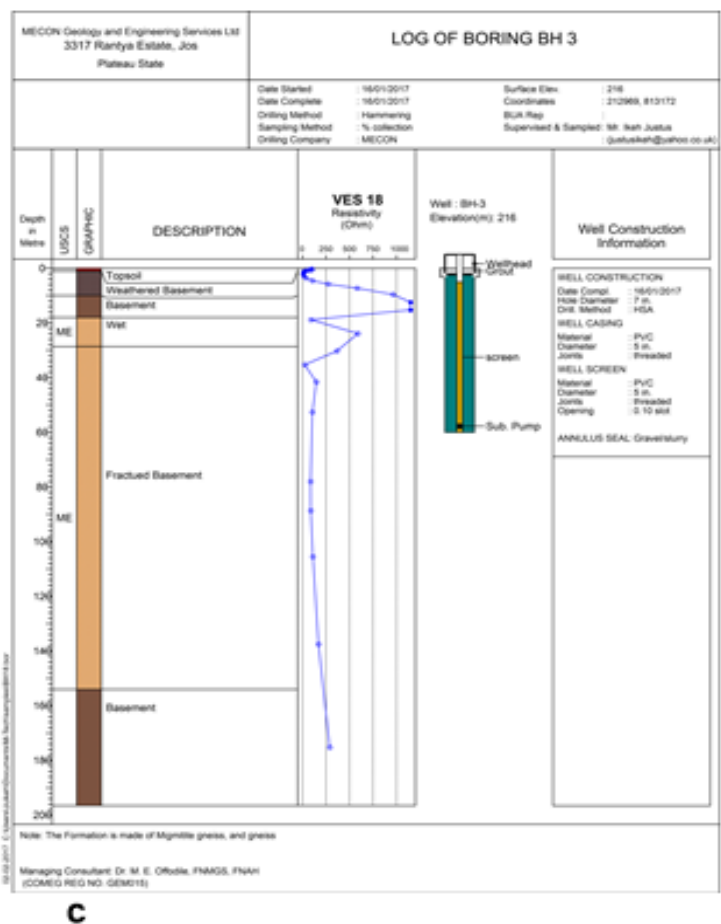

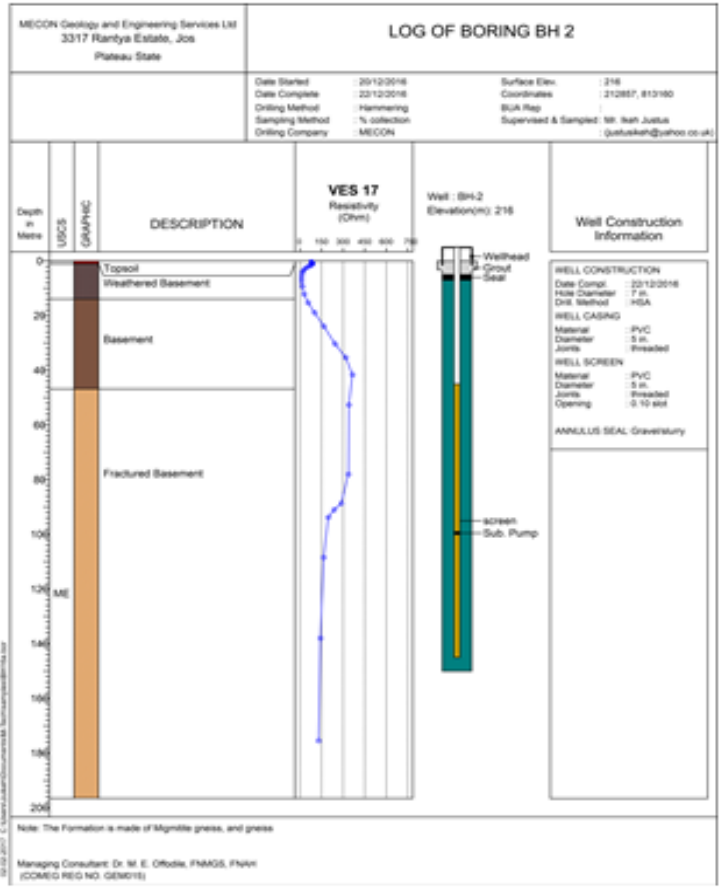

b

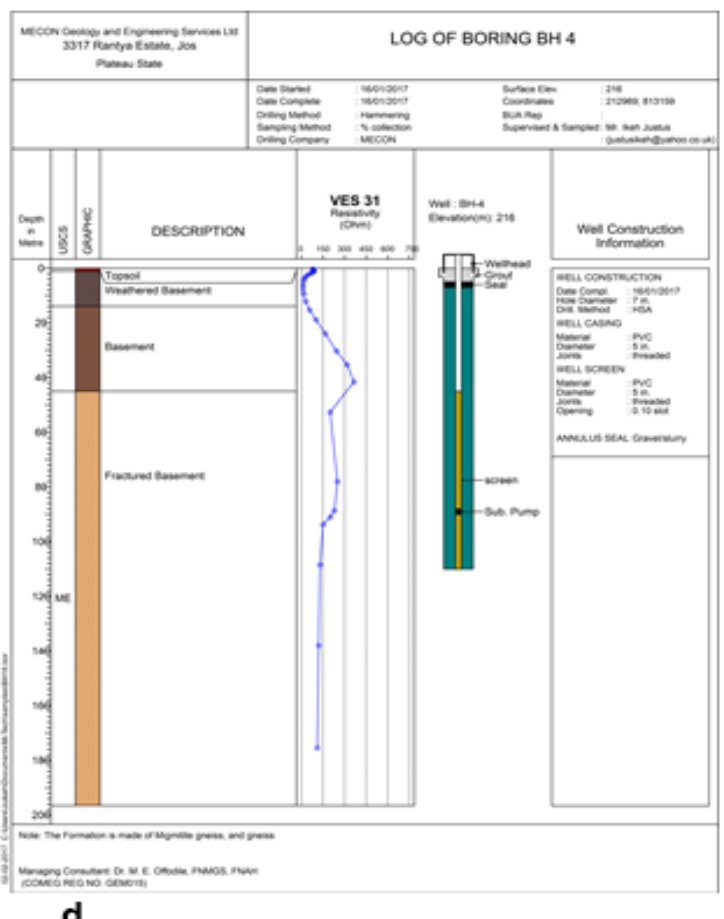

d

Fig. 5: VES-Borehole correlation (Source: Mecon Geology and Engineering Services Ltd.) 


\section{Pumping Test}

Pumping test regime 2 horse power (1,348kw) pump for 24 hours period was carried out on the four exploratory boreholes and the hydrogeologic characteristics are presented in Table 2. The borehole flow rates are $1.4,2.15,2.0$ and 2.08 litres/sec for the exploratory boreholes numbered $\mathrm{BH} 1, \mathrm{BH} 2, \mathrm{BH} 3$ and $\mathrm{BH} 4$ respectively. From pumping rate versus time and time-drawdown graphs (Fig. 6 and Fig. 7) for the boreholes shows that the boreholes pumping rates started with 1.4, 2.15, 2.0 and 2.08 litres/sec and stabilized at $0.18,1.87,1.79$ and 1.97 litres/sec flow rates after 30, 5, 2 and 1.5 minutes for $\mathrm{BH} 1, \mathrm{BH} 2, \mathrm{BH} 3$ and $\mathrm{BH} 4$ respectively. The transmissivity values for the boreholes was calculated using Jacob method.

The Jacob equation is, $T=\frac{2.3 Q}{4 \pi \Delta h}$

where, $\mathrm{T}=$ transmissivity $\left(\mathrm{m}^{2} /\right.$ day $)$,

$\Delta h=$ slope of drawdown verses time (m)

$\mathrm{Q}=$ flow rate $\left(\mathrm{m}^{2} /\right.$ day $)$.

The transmissivity values of $2.58 \mathrm{~m}^{2} /$ day, $21.43 \mathrm{~m}^{2} /$ day, $55.62 \mathrm{~m}^{2} /$ day, and $37.98 \mathrm{~m}^{2} / \mathrm{day}$ for BH1, BH2, BH3 and BH4 respectively were calculated from the Time-drawdown graphs (Fig. 7 and Table 2. The transmissivity value and groundwater potential evaluation of the exploratory boreholes (Table 3) is evaluated according to Reddy, 2014 classification. Three of the boreholes potential water supply capacities are suitable for decentralized small community water supply schemes and for small to medium industries depending on water supply requirment.

Table 2: Summary of hydrogeologic characteristics of the exploratory boreholes around Obu-Okpella.

\begin{tabular}{|c|c|c|c|c|c|c|c|c|c|}
\hline $\begin{array}{l}\text { Borehole } \\
\text { Number }\end{array}$ & $\begin{array}{l}\text { Date } \\
\text { drilling }\end{array}$ of & $\begin{array}{l}\text { Total } \\
\text { depth(m) }\end{array}$ & Aquifer type & $\begin{array}{l}\text { Pumping time } \\
\text { (hrs) }\end{array}$ & $\begin{array}{l}\text { Initial } \\
\text { yield }(/ \mathrm{s})\end{array}$ & $\begin{array}{l}\text { Average Flow rate after } \\
\text { stabilization }(/ / s)\end{array}$ & $\begin{array}{l}\text { Discharge } \\
\text { (/day) }\end{array}$ & Jacob equation $\left(h 1-h 2=\frac{23 Q}{4 \pi T}\right)$ & $\begin{array}{l}\text { Transmissivity, } \\
\mathbf{T}\left(\mathrm{m}^{2} / \text { day }\right)\end{array}$ \\
\hline BH1 & $11 / 12 / 2016$ & & $\begin{array}{l}\text { Fractured } \\
\text { basement }\end{array}$ & & & 0.18 & & $\begin{aligned} 0.96-0 & =\frac{2.3 \times 15.552}{4} \times 3.142 \\
\mathrm{~T} & =2.58 \quad \times T\end{aligned}$ & 2.58 \\
\hline $\mathrm{BH} 2$ & $22 / 12 / 2016$ & 150 & $\begin{array}{l}\text { Fractured } \\
\text { basement. }\end{array}$ & 24 & 2.15 & 1.87 & 161,568 & $0.66-0.06=\frac{2.3 \times 161.56}{4 \times 3.142 \times T}$ & 21.43 \\
\hline BH3 & $16 / 01 / 2017$ & 60 & $\begin{array}{l}\text { Fractured } \\
\text { basement. }\end{array}$ & 24 & 2.00 & 1.97 & 170,208 & $\begin{array}{c}\mathrm{T}=21.43 \\
0.56-0=\frac{2.3 \times 170.208}{4} \times 3.142\end{array}$ & 55.62 \\
\hline BH4 & $16 / 01 / 2017$ & 110 & $\begin{array}{l}\text { Fractured } \\
\text { basement. }\end{array}$ & 24 & 2.08 & 1.20 & 103,680 & $\begin{aligned} T=55.62 \\
0.56-0.06=\frac{2.3 \times 103.680}{4} \\
T=37.98 \quad \times 3.142 \times T\end{aligned}$ & 37.98 \\
\hline
\end{tabular}

Table 3: Transmissivity and groundwater supply potential evaluation.

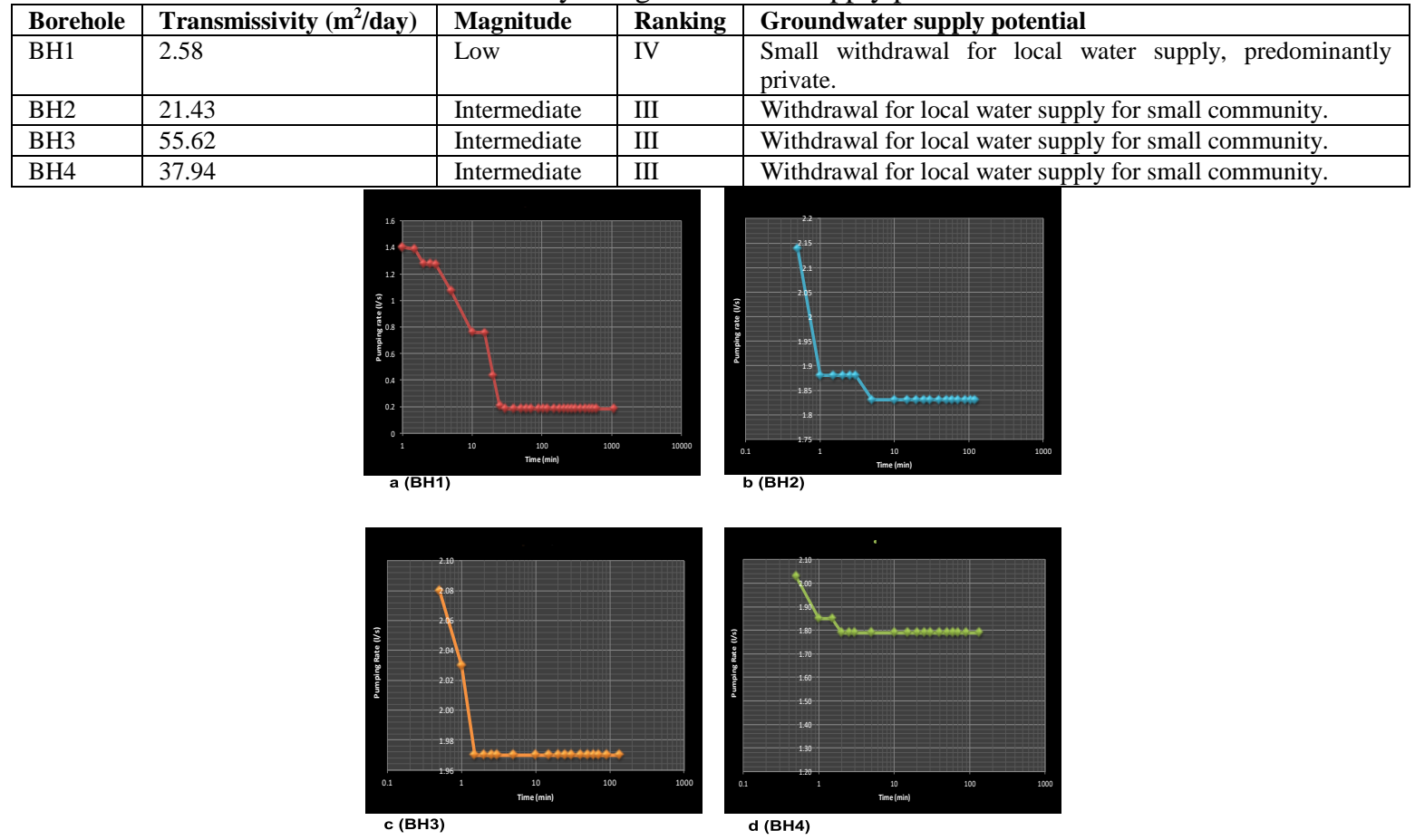

Fig. 6: Pumping rate verses Time graph 


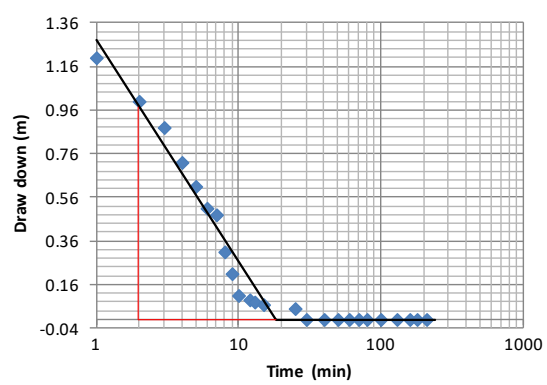

a (BH1)

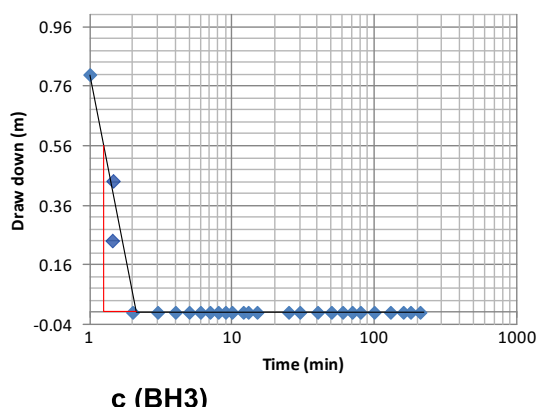

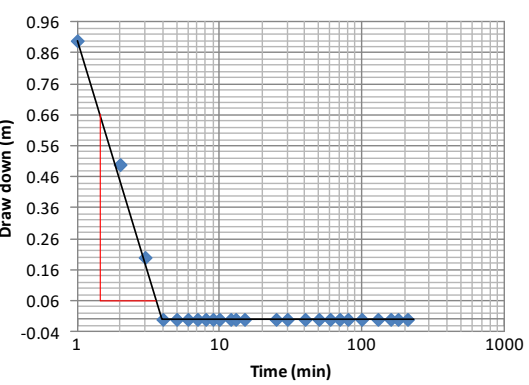

b (BH2)

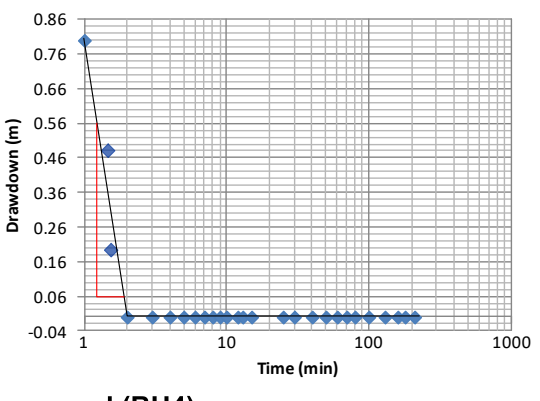

d (BH4)

Fig. 7: Draw down verses Time graph

\section{Conclusion}

An integrated geo-electric and hydrogeologic investigation methods were employed to explore the groundwater resources of Obu-okpella south of the BUA Cement factory. The geo-electric resistivity investigations revealed the generalized subsurface geo-electric layers/lithologic units to consists of -Topsoil $(<2 \mathrm{~m})$, weathered basement (from 0.6 to $49 \mathrm{~m}$ ), fresh/fractured basement (consisting of sand/sandy clay) with resistivity value of 14 to $297 \mathrm{ohm}-\mathrm{m}, 16$ to $98 \mathrm{ohm}-\mathrm{m}$, > $2600 \mathrm{ohm}-\mathrm{mand}<50$ to $31056 \mathrm{ohm}-\mathrm{m}$ respectively. Exploratory borehole drilling numbered $\mathrm{BH} 1, \mathrm{BH} 2, \mathrm{BH} 3$ and $\mathrm{BH} 4$ were drilled to depths of 202, 150. 110 and 60m on VES No. 1, 18, 17 and 31 respectively to determine the hydrogeologic characteristics, especially yield etc. The borehole lithologic $\log$ correlated well with the geo-electric parameters derived from the geo-electric sounding interpretations.

From the pumping test, the flow rate and calculated transmissivity values are $0.18,1.87,1.97,1.2 \mathrm{litre} / \mathrm{sec}$ and $2.58 \mathrm{~m}^{2} /$ day, $21.43 \mathrm{~m}^{2} /$ day, $55.62 \mathrm{~m}^{2} /$ day and $37.98 \mathrm{~m}^{2} /$ day for $\mathrm{BH} 1, \mathrm{BH} 2, \mathrm{BH} 3$ and $\mathrm{BH} 4$ respectively. The combine flow rates (output) of the boreholes is 451,012 litres/day.

Based on the geo-electric/hydrogeologic characteristics of the area, Obu-Okpella has a good groundwater potential. Ground water resources can be harness for domestic and industrial use. However, systematic and detail exploratory methods involving geophysical and drilling program will assist in the proper assessment of the groundwater resources for small and medium town water supply scheme.

\section{Acknowledgement}

The authors wish to acknowledge the contributions of Meecon Geology and Engineering Services Nig. Ltd. for supplying the borehole lithostratigraphic logs and geophysical survey data used for this work.

\section{References}

[1]. Bala A.E and Ike E.C, 2001: The aquifer of the crystalline rocks of Gusam area, Northwestern Nigeria. Journal of Mining \& Geology, Vol. 37, No. 2, pp 177-184.

[2]. Balogun O., Adebisi A.O and Folami S.L (2000): Groundwater potential of Rido, near Kaduna, NW Nigeria. Water Resources, Vol 11, pp 21-25

[3]. Dan-Hassan M.A and Olurufemi M.O, (1991): Hydrogeophysical investigation of a basement terrain in north central part of Kaduna State, Nigeria. Journal of Mining \& Geology Vol.35 (2), pp 189-206.

[4]. du Preez J.W and Berber (1965): The Distribution of Chemical Quality of Groundwater in Northern Nigeria Geological Bulletin No. 36.

[5]. Longpia C.B, Ashano E.C and Pam B.G, (2013: Geophysical Investigation for Engineering Site Development Around GaladimawaAleita Area, Abuja North Central Nigeria. ISOR Journal Applied Geology and Geophysics Vol.1 (6).pp1-11. 
[6]. Longpia C.B, Nkolo N and Dakwo P.D (2014): A Priminary Geophysical Survey of the Limestone/Dolimite-Shales of the Comba Trough, Buenza Region, South Congo: Implication for Groundwater Exploration and Development. Contenantal Journal of Earth Science 9(1) pp 30-38.

[7]. Offodile M.E, (1983): The Occurrence and Exploration of Groundwater in Nigeria Basement Rocks J. Mining and Geology Vol. No. 20 (1\&2), pp 131-146.

[8]. Offodile M.E, (2002): Groundwater study and Development in Nigeria. Mecon Services Ltd, Jos.

[9]. Olayinka A.T. and Olorufemi M.O, (1992): Determination of geo-electrical Characteristics in Okene area and implications for borehole siting. Journal of Mining \& Geology Vol. 28(2) pp 403-412.

[10]. Olorufemi M.O \& Okhue E.T, (1992): Hydrgeologic \& geologic significance of geo-electric survey at Ile-Ife. Journal of Mining \& Geology Vol. SS28 (2) pp 221-229.

[11]. Omusuyi G.O, Ojo J.S. and Erikanselu P.A, (2003): Geophysical Investigation for Groundwater Around Obanle-Obakekere in Akure Area within the Basement Complex of Southwestern Nigeria pp 109-116.

[12]. Rahaman M. A (1989): Review of the Geology of South-western Nigeria In: Geology of Nigeria. ed. C.A Kogbe. Rock view Nig. Ltd, Jos.

[13]. Reddy K.S, (2014): Classification of transmissivity magnitude and variation in calcareous soft rocks of Bhaskar Rao Kunta Watershed, Nalgonda District, India. International Journal of Water Resources and Environmental Engineering. Vol. 6(3), pp 106-111. 